\title{
Enhancement of the Dense-Core Vesicle Secretory Cycle by Glucocorticoid Differentiation of PC12 Cells: Characteristics of Rapid Exocytosis and Endocytosis
}

\author{
Abdeladim Elhamdani, ${ }^{1}$ Mary E. Brown, ${ }^{2}$ Cristina R. Artalejo, ${ }^{1}$ and H. Clive Palfrey ${ }^{2}$ \\ ${ }^{1}$ Department of Pharmacology, Wayne State University School of Medicine, Detroit, Michigan 48201, and ${ }^{2}$ Department of \\ Neurobiology, Pharmacology and Physiology, University of Chicago, Chicago, Illinois 60637
}

\begin{abstract}
The secretory cycle of dense-core vesicles (DCVs) in physiologically stimulated patch-clamped PC12 cells was analyzed using both amperometry and capacitance measurements. Untreated cells had low or undetectable Ca currents and sparse secretory responses to short depolarizations. Dexamethasone (5 $\mu \mathrm{M}$ ) treatment for 5-7 d tripled Ca current magnitude and dramatically increased quantal secretion in response to depolarization with action potentials. Such cells expressed L-, N-, and $\mathrm{P}$-type $\mathrm{Ca}$ channels, and depolarization evoked rapid catecholamine secretion recorded as amperometric spikes; the average latency was $\sim 50 \mathrm{msec}$. These spikes were much smaller and shorter than those of primary adrenal chromaffin cells, reflecting the smaller size of DCVs in PC12 cells. Depolarizing pulse trains also elicited a rapid increase in membrane capacitance corresponding to exocytosis in differentiated but not in naïve cells. On termination of stimulation, membrane
\end{abstract}

capacitance declined within $20 \mathrm{sec}$ to baseline indicative of rapid endocytosis $(R E)$. $R E$ did not take place when secretion was stimulated in the presence of $\mathrm{Ba}$ or $\mathrm{Sr}$, indicating that RE is Ca-specific. RE was blocked when either anti-dynamin antibodies or the pleckstrin homology domain of dynamin-1 was loaded into the cell via the patch pipette. These studies indicate that neuroendocrine differentiation of PC12 cells with glucocorticoids enhances the development of the excitable membrane and increases the coupling between $\mathrm{Ca}$ channels and vesicle release sites, leading to rapid exocytosis and endocytosis. Slow catecholamine secretion in undifferentiated cells may be caused in part by a lack of localized secretory machinery rather than being an intrinsic property of dense-core vesicles.

Key words: exocytosis; endocytosis; PC12 cell; dense-core vesicle; secretory cycle; calcium current; glucocorticoid; catecholamine secretion
Secretion in nerve terminals and neuroendocrine cells is a complex process involving many steps (Sudhof, 1995; Martin, 1997; Palfrey and Artalejo, 1998). Under physiological conditions, exocytosis of hormone or neurotransmitter depends on $\mathrm{Ca}$ influx through voltage-dependent $\mathrm{Ca}$ channels. The proximity of secretory vesicles to $\mathrm{Ca}$ channels is one of the parameters determining the speed of transmitter release. At nerve terminals containing small synaptic vesicles, such channels are close to release sites in the active zone, leading to minimal delay between Ca entry and exocytosis ( $\sim 1 \mathrm{msec}$ ) (Sabatini and Regehr, 1999). By contrast, in certain neuroendocrine cells and nerve terminals containing dense-core vesicles (DCVs), release sites and Ca channels may be dispersed, leading to a delay in secretion (Chow et al., 1992; Klingauf and Neher, 1997). These data have contributed to the popular view that secretion from DCVs is always slower and less efficient than that from small synaptic vesicles (Kasai, 1999). We recently showed, however, that catecholamine secretion is strongly coupled to a particular type of $\mathrm{Ca}$ channel in bovine calf (but not adult) chromaffin cells (Elhamdani et al., 1998), resulting in fast release kinetics $\left(3 \mathrm{msec}\right.$ latency at $\left.24^{\circ} \mathrm{C}\right)$. Thus DCV exocytosis rates in chromaffin cells are heterogeneous, and de-

Received Oct. 29, 1999; revised Jan. 10, 2000; accepted Jan. 20, 2000.

This work was supported by a grant from the United States Public Health Service (GM-56396). We thank Drs. Thomas F. J. Martin and Greg Kapatos for supplying some of the PC12 cells used in these experiments.

Correspondence should be addressed to Dr. H. Clive Palfrey, Department of Neurobiology, Pharmacology and Physiology, University of Chicago, 947 E. 58th Street, Chicago, IL 60637. E-mail: hpalfrey@midway.uchicago.edu.

Copyright (C) 2000 Society for Neuroscience $0270-6474 / 00 / 202495-09 \$ 15.00 / 0$ velopment may alter the manner in which catecholamine secretion is regulated in the intact organism. The secretory cycle is completed by the process of endocytosis, whereby presumptive vesicular membrane is recaptured (for review, see Henkel and Almers, 1996; Palfrey and Artalejo, 1998). Membrane retrieval after stimulated secretion in calf chromaffin cells is a highly reproducible and distinctive event that we termed "rapid endocytosis" (RE) (Artalejo et al., 1995, 1996, 1997) to distinguish it from coated vesicle-based endocytosis. Little is known about the developmental regulation of this process.

To further analyze the secretory cycle of DCVs in development, it would clearly be advantageous to work with a neuroendocrine cell line that could undergo differentiation to a mature phenotype and be genetically modifiable with relative ease. The rat pheochromocytoma PC12 line (Greene and Tischler, 1976) has been used extensively in studies of catecholamine secretion and vesicle biogenesis. These cells contain the biosynthetic machinery for norepinephrine synthesis and storage in DCVs that undergo secretion on depolarization (Greene and Tischler, 1976; Greene and Rein, 1977). Growing cells are thought to resemble sympathoadrenal precursors and to differentiate toward a more chromaffin-like phenotype on treatment with glucocorticoids (Schubert et al., 1980; Tischler et al., 1983) or to a more sympathetic neuron phenotype on treatment with NGF (Greene and Tischler, 1976). Glucocorticoids upregulate catecholaminesynthesizing enzymes and storage proteins (Schubert et al., 1980; Tischler et al., 1983; Kim et al., 1993, Rozansky et al., 1994), whereas NGF treatment has little effect on the levels of stored catecholamines (Greene and Tischler, 1976). It is surprising, 
therefore, that catecholamine secretion has been studied predominantly in untreated or NGF-differentiated PC12 cells.

Much of the aforementioned work evaluated bulk secretion biochemically using chronic stimulation conditions. This approach lacks temporal precision, and neither the quantal properties of secretion nor the endocytotic recovery processes that ensue are amenable to analysis. The few examinations of single-cell secretory responses have used chronic stimulation paradigms involving massive intracellular $\mathrm{Ca}$ loading or high $[\mathrm{K}]$ depolarization (Kasai et al., 1996; Zerby and Ewing, 1996). Even with such supraphysiological stimuli, catecholamine secretion and putative DCV-related endocytotic processes are quite slow in growing cells. Here we show that PC12 cells express substantially increased $\mathrm{Ca}$ currents after glucocorticoid treatment, as well as markedly enhanced secretory capacity, as detected by amperometric recording of quantal catecholamine release and capacitance recording of cell surface area. Differentiated cells exhibit highly efficient coupling (average delay $\sim 50 \mathrm{msec}$ ) between action potentials (APs) and catecholamine secretion that is mediated by $\mathrm{Ca}$ channel activation. Moreover, exocytosis in differentiated cells is immediately followed by RE that resembles the process in calf chromaffin cells. These properties suggest that adrenotopic differentiation of PC12 cells is accompanied by development of the secretory apparatus toward a mature chromaffin cell phenotype.

\section{MATERIALS AND METHODS}

\section{Cell culture}

PC12 cells were cultured as described previously (Brady et al., 1990). For most of the experiments, cells were plated at a density of $3 \times 10^{5}$ cells onto collagen- or poly-L-lysine-coated $35 \mathrm{~mm}$ dishes. For glucocorticoid differentiation, cells were treated with $5 \mu \mathrm{M}$ dexamethasone (Sigma, St. Louis, MO) with daily exchange of medium. Analysis of these cells was performed 2-7 d after the beginning of treatment. Cells were routinely checked for mycoplasma contamination by DNA staining and fluorescence microscopy. Mycoplasma was found to render cell membranes extremely leaky, making electrophysiological analysis difficult. Calf adrenal chromaffin (AC) cells were prepared and cultured as described previously (Elhamdani et al., 1998).

\section{Electrophysiology}

Conventional patch-clamp current and capacitance recording. Our patchclamp techniques have been published previously (Artalejo et al., 1995). $\mathrm{Ca}$ currents were recorded and quantitated as described (Artalejo et al., 1994). The following Ca channel antagonists were added to the external solution to suppress individual Ca current components: PN200-110 $(1 \mu \mathrm{M}), \omega$-conotoxin GVIA $(\omega$-CgTx; $500 \mathrm{nM})$, and $\omega$-agatoxin IVA $(\omega$-AgaTx;100 nM). In most experiments, a solution containing the drugs dissolved in the external solution was applied directly to the cells via narrow-bore capillary tubing placed within $50 \mu \mathrm{m}$ of the cell surface. Perfusion rates were computer-controlled, and complete bath exchange occurred in 100-200 msec. Capacitance was measured by a computer program using a phase-tracking technique. A standard protocol of ten $50 \mathrm{msec}$ depolarizations from a holding potential of $-90 \mathrm{mV}$ to $+10 \mathrm{mV}$ was used to evoke secretion. After the secretory phase, RE manifests as a decrease in capacitance; both the rate and extent of RE were measured, as well as the rate and extent of exocytosis. All experiments were performed at room temperature $\left(24^{\circ} \mathrm{C}\right)$. The standard patch pipette solution contained (in mM): Cs-glutamate 110, Cs-EGTA 0.1, HEPES $40, \mathrm{MgCl}_{2}$ 5, ATP 2, GTP 0.35, pH 7.2, with $\mathrm{CsOH}$ (nucleotides were added fresh to the stock salt solution just before the experiment). Anti-pan-dynamin IgGs (Artalejo et al., 1995) or human dynamin-1 pleckstrin homology (PH) domain (Artalejo et al., 1997) were centrifugally dialyzed against internal pipette solution in Centricon-20 spin concentrator devices (Amicon, Beverly, MA) before introduction into the cell. The standard external solution consisted of (in $\mathrm{mM}$ ): $\mathrm{CaCl}_{2} 5$, TEA-Cl 150 , HEPES 10 , glucose $10, \mathrm{MgCl}_{2} 1$, and $1 \mu \mathrm{M}$ tetrodotoxin, $\mathrm{pH}$ 7.3. For $\mathrm{Ca}$ channel characterization, external $\mathrm{Ca}$ was replaced by $\mathrm{BaCl}_{2}(10 \mathrm{~mm})$ with a reduction of TEA-Cl to $140 \mathrm{mM}$. In divalent cation substitution capacitance experiments, $\mathrm{Ca}$ was replaced on an equimolar basis with Ba or Sr salts.

Current-clamp recording. To evoke action potentials, cells maintained at a $V_{\mathrm{m}}$ of -70 to $-90 \mathrm{mV}$, through application of a holding current of -1 to $-4 \mathrm{pA}$, were stimulated by depolarizing currents $(+20$ to $+40 \mathrm{pA})$ of $20 \mathrm{msec}$ (Elhamdani et al., 1998, 1999). An eight-pole Bessel filter was set to a corner frequency of $2 \mathrm{kHz}$ for $V_{\mathrm{m}}$ recording, then sampled at 5 $\mathrm{kHz}$. The pipette solution contained (in mM): K-glutamate 100, K-EGTA 0.1, $\mathrm{NaCl} 12$, HEPES 30, $\mathrm{MgCl}_{2}$ 5, ATP 2, GTP 0.35, pH 7.2, with KOH. The external solution consisted of (in $\mathrm{mm}$ ): $\mathrm{NaCl} 140$, glucose 10, HEPES 10, $\mathrm{MgCl}_{2} 1, \mathrm{KCl} 5.5, \mathrm{CaCl}_{2} 2$, $\mathrm{pH} 7.3$, with $\mathrm{NaOH}$.

Carbon fiber amperometry for catecholamine detection. Highly sensitive low-noise polypropylene-insulated carbon-fiber electrodes (ProCFE) were prepared and used for electrochemical monitoring of quantal release of catecholamines from single cells as described (Wightman et al., 1995; Chow et al., 1992; Elhamdani et al., 1998, 1999). Each ProCFE was then used in a maximum of one to three cells to ensure the highest possible sensitivity. The tip of the electrode was closely apposed to the cell surface to minimize the diffusion distance from release sites. The amperometric current $\left(I_{\mathrm{amp}}\right)$, generated by oxidation of catecholamines at the exposed tip of the CFE, was measured using an Axopatch 200A amplifier, operated in the voltage-clamp mode at a holding potential of $+780 \mathrm{mV}$, sufficient to detect all released catecholamines [PC12 cells release dopamine and norepinephrine in variable proportions with dopamine generally predominant (Greene and Rein, 1977; Schubert et al., 1980)]. Amperometric signals were low-pass-filtered at $2 \mathrm{kHz}$, then sampled at $5 \mathrm{kHz}$ by an Axobasic system. The data were collected, then analyzed by computer using IGOR software (WaveMetrics, Lake Oswego, OR) exactly as previously described (Elhamdani et al., 1998, 1999). Latencies (defined as the time from the peak of the AP to the beginning of the current spike) were analyzed using latency histograms; the beginning of the current spike was located where the leading edge of the transient (which includes the "foot" signal when present) exceeded the baseline current by two times the SD of the baseline noise level. Measurements are given as means \pm SEM. Depolarization in some cases was also elicited by puffer application of an external solution in which [K] was raised to $60 \mathrm{~mm}$ with an equivalent reduction of [ $\mathrm{Na}]$.

\section{Analysis of dynamin expression in PC12 cells}

Extracts of rat brain synaptosomes, PC12 cells, and mouse 3T3 fibroblasts were prepared by sonication in a lysis buffer containing (in $\mathrm{mM}$ ): Tris-HCl 50, pH 7.4, EDTA 2, EGTA 1, 2-mercaptoethanol 5, PMSF 0.3, and leupeptin 0.1. After sonication, aliquots were taken for protein assay, and the extracts were immediately solubilized in SDS sample buffer. Samples (10-75 $\mu \mathrm{g}$ protein) were separated by SDS-7.5\% PAGE; proteins were transferred to nitrocellulose and subjected to immunoblotting procedures as described previously (Artalejo et al., 1995). Affinitypurified goat polyclonal anti-dynamin-1- and dynamin-2-specific IgGs were obtained from Santa Cruz Biotechnology and used at concentrations of 0.2 and $0.15 \mu \mathrm{g} / \mathrm{ml}$, respectively. Detection was with rabbit anti-goat IgG peroxidase and enhanced chemiluminescence.

\section{RESULTS \\ Glucocorticoid treatment increases $\mathbf{C a}$ currents in PC12 cells}

To assess whether PC12 cell differentiation toward a chromaffin cell phenotype is accompanied by modification of $\mathrm{Ca}$ channel populations, we compared total $\mathrm{Ca}$ currents (using $\mathrm{Ba}$ as charge carrier) in untreated cells and those exposed to dexamethasone for 2-7 d (Fig. 1). Patch-clamp analysis of undifferentiated PC12 cells revealed very low $\mathrm{Na}$ and $\mathrm{Ca}$ current amplitudes in virtually all cells (cf. Dichter et al., 1977; Streit and Lux, 1987; Janigro et al., 1989; Usowicz et al., 1990), but glucocorticoid treatment caused a progressive approximately threefold increase in the magnitude of $\mathrm{Ca}$ currents over a $7 \mathrm{~d}$ period (Fig. $1 A$ ). Ca current components in these cells were evaluated using drugs or toxins to dissect specific channel types. Figure $1 B$ shows peak $I-V$ curves from an untreated and dexamethasone-treated PC12 cell under control conditions, in the presence of the dihydropyridine antagonist PN200-110 to block L-type Ca currents, or $\omega$-CgTx and $\omega$-AgaTx to block $\mathrm{N}$ - and P-type current components, respec- 
A

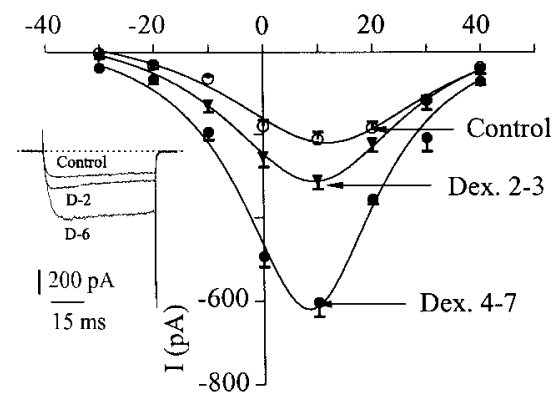

B

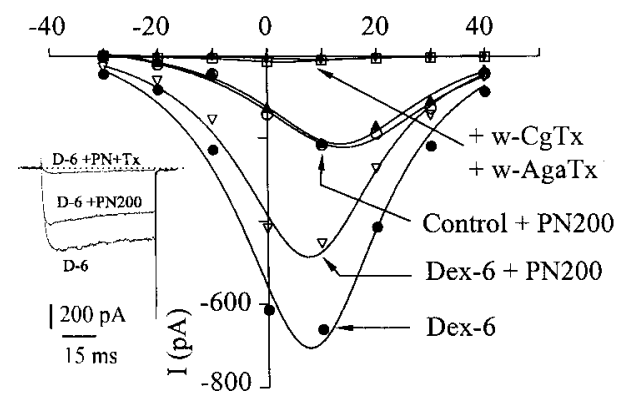

Figure 1. Dexamethasone treatment of PC12 cells increases Ca current density. Ca current $I-V$ curves were constructed by depolarizing $(50 \mathrm{msec})$ from a holding potential of $-90 \mathrm{mV}$ to the potential indicated. $A$, Averaged data from control $(n=27), 2-3 \mathrm{~d}$ dexamethasone-treated (Dex. 2-3) $(n=5)$, and 4-7 d dexamethasone-treated (Dex. 4-7) $(n=$ 16) cells. Dexamethasone led to a 46 and $283 \%$ increase in Ca current magnitudes at the early and late times of treatment, respectively. $B$, The standard $\mathrm{Ca}$ current in untreated cells $(O)$ is insensitive to the dihydropyridine antagonist PN200-110 $(1 \mu \mathrm{M} ; \mathbf{\Delta})$ but is completely blocked by a combination of $\omega$-Cgtx (500 nM) and $\omega$-AgaTx (100 nM) ( $\square$ ). By contrast, in $6 \mathrm{~d}$ dexamethasone-treated $($ Dex -6$)$ cells $(-)$, current is partially blocked by PN200-110 $(\nabla)$, with the residual current being abolished by the toxin combination. Recordings from typical cells are shown; averaged data are presented in Table 1. Insets show typical Ca currents in each condition.

tively. Naïve cells had barely detectable L-type Ca currents, and PN200-110 had virtually no effect; the current in these cells appeared to be primarily $\mathrm{N}$ - and P-types because it was entirely suppressed by the toxin combination. By contrast, in dexamethasone-treated cells $\sim 31 \%$ of the current was carried by L-type Ca channels with the remainder carried by $\mathrm{N}$ - and P-type channels as estimated by toxin inhibitors. These results, summarized in Table 1, agree with previous reports indicating that dexamethasone increases overall $\mathrm{Ca}$ current density, particularly L-type currents, in primary rat and porcine adrenal chromaffin cells in culture (Fuller et al., 1997a,b). Voltage-dependent facilitation of L-type currents, of the type seen in epinephrinesecreting calf AC cells (Artalejo et al., 1994; Elhamdani et al., 1998), was not reproducibly seen in differentiated PC12 cells, in line with other studies indicating that norepinephrine-containing cells in the calf adrenal lack facilitation L-type $\mathrm{Ca}$ channels (C. R. Artalejo and A. Elhamdani, unpublished results).

\section{Dexamethasone enhances quantal secretion in PC12 cells: amperometric analysis}

Given that glucocorticoid treatment increases both $\mathrm{Ca}$ current density and catecholamine synthesis, it seemed likely that secretory responses in these cells would also be enhanced. Quantal exocytosis was evaluated by amperometric detection of released
Table 1. Statistical analysis of Ca currents in untreated and dexamethasone-treated PC12 cells

\begin{tabular}{lllll} 
& & Peak current & & \multicolumn{4}{l}{ Current type $(\%)^{c}$} \\
\cline { 5 - 6 } Treatment $^{a}$ & $(\mathrm{pA})$ & $\mathrm{L}$ & $\mathrm{N}$ & $\mathrm{P} / \mathrm{Q}$ \\
\hline None $(n=27)$ & $213 \pm 15.5$ & 0 & $100^{d}$ & \\
Dex 2-3 d $(n=19)$ & $311 \pm 22$ & & & \\
Dex 4-7 d $(n=16)$ & $603 \pm 41$ & $31 \pm 4$ & $45.6 \pm 2.9$ & $23.4 \pm 1.5$
\end{tabular}

$\bar{a}$ PC12 cells were left untreated or incubated in the presence of dexamethasone (Dex, $5 \mu \mathrm{M}$ ) for $2-3$ or $4-7 \mathrm{~d}$.

${ }^{b}$ Peak $\mathrm{Ba}^{2+}$ current at $+10 \mathrm{mV}$ (mean \pm SEM).

${ }^{c}$ Pharmacological dissection of different types of current was performed in 10 cells using PN200-110 (1 $\mu \mathrm{M}), \omega$-Cgtx (500 nM), and $\omega$-AgaTx (100 nM) to block L-, N-, or P-type current, respectively.

${ }^{d} \mathrm{~N}$ and $\mathrm{P} / \mathrm{Q}$ were not determined separately.
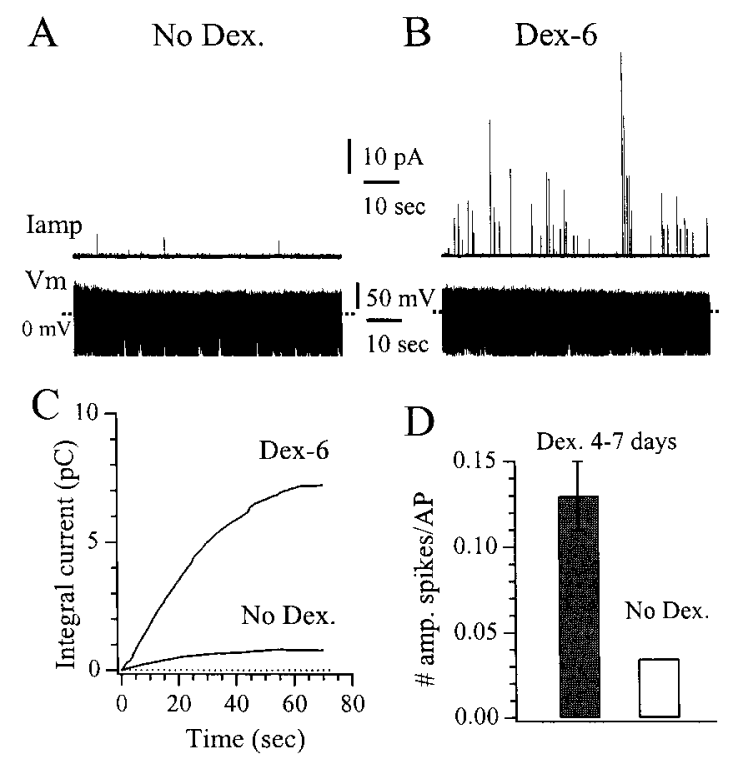

Figure 2. Dexamethasone dramatically increases quantal catecholamine secretion. Untreated (A, No Dex.) or $6 \mathrm{~d}$ dexamethasone-treated $(B$, Dex -6$)$ PC12 cells were stimulated by a train of 490 action potentials $\left(V_{\mathrm{m}}\right)$ at $7 \mathrm{~Hz}$ (bottom trace), and the resultant catecholamine secretion was detected by a carbon fiber electrode in close apposition to the cell surface (top trace). The electrode was held at a potential of $+780 \mathrm{mV}$ to oxidize all catecholamines released. Untreated cells showed poor secretion $(n=2)$ as in $A$ or no secretion $(n=16)$. Dexamethasone treatment resulted in markedly increased secretion as recorded in individual amperometric spikes. $C$, Total catecholamine secretion, represented as the summed integral of amperometric spikes versus time, is markedly increased in dexamethasonetreated cells. $D$, The probability of release of DCVs in PC12 cells was increased by dexamethasone treatment from $<0.03$ to 0.13 amperometric spike per AP.

catecholamines (Wightman et al., 1995; Chow et al., 1992; Elhamdani et al., 1998) (for review, see Travis and Wightman, 1998) on stimulating the cells with trains of action potentials or pufferapplied high $[\mathrm{K}]$. Naïve PC12 cells showed minimal secretory responses to depolarizing pulse trains ( 2 of 18 cells studied) (Fig. $2 A$ ) or $60 \mathrm{~mm} \mathrm{KCl} \mathrm{(data} \mathrm{not} \mathrm{shown),} \mathrm{whereas} \mathrm{all}$ dexamethasone-treated cells $(n=14)$ showed dramatically enhanced secretion (Fig. 2B,C). The probability that a secretory event would occur in response to depolarization was also markedly increased after dexamethasone treatment (Fig. 2D). Under these conditions, application of PN200-110 reduced total catecholamine release by $\sim 44 \pm 5 \%(n=6)$ in dexamethasone- 



treated cells, with the remaining secretion being completely blocked by a combination of $\omega$-CgTx and $\omega$-AgaTx.

Casual inspection of typical unitary events revealed that those from differentiated PC12 cells appeared much smaller and briefer than those derived from calf AC cells (Fig. 3Aa1, Bb1). To establish the characteristics of quantal secretion in PC12 cells and compare them with those of calf chromaffin cells, we statistically analyzed four distinctive parameters of these spikes, as exemplified in Figure 3Aa2, Bb2: maximum spike amplitude, total charge (or quantal content; $Q$ ) including the "foot" (Chow et al., 1992) when present, rise time $(R T)$, and half width $(H W)$. Spike amplitude and charge histograms reflect the amount and distribution of catecholamine released per quantal event (for review, see Travis and Wightman, 1998), whereas the rise time and half width give an indication of the speed of hormone release from secreting vesicles. Mean amplitude values of 32 versus $117 \mathrm{pA}$ (Fig. 4A) and half width values of 1.9 versus $6.2 \mathrm{msec}$ (Fig. $4 D$ ) were obtained for PC12 and calf AC cells, respectively. Charge histograms revealed that the amount of catecholamine released per spike is $<7 \%$ of the average equivalent event from calf AC cells (Fig. 4B) (cf. Elhamdani et al., 1998, 1999). No difference in the characteristics of spikes elicited by puffer-applied high $[\mathrm{K}]$ as opposed to action potentials was evident. These data, summarized in Table 2, confirm that quantal spikes in PC12 cells are smaller and faster than those in calf AC cells.

As described previously by Finnegan et al. (1996), we found that the statistical distribution of quantal content in both PC12 and calf AC cells was Gaussian when plotted as the cube root of the total amperometric charge (average cubic root charge, $Q^{1 / 3}$, was $378 \mathrm{fC}$ for differentiated PC12 cells and $960 \mathrm{fC}$ for calf AC cells) (Table 2). These values predict that AC cell DCVs are $\sim 2.5$ times larger, on average, than those in PC12 cells, assuming approximately equal catecholamine concentrations in both types of $\mathrm{DCV}$, and are concordant with the measured mean DCV radii of 170-230 nm [bovine AC (Finnegan et al., 1996) calculated from the data of Coupland (1968)] and 79-100 nm [PC12 (Schubert et al., 1980)], derived from electron micrographs. Because noradrenergic vesicles are thought to be smaller than adrenergic DCVs in the adrenal medulla (Tomlinson et al., 1987), these results are consistent with the primarily noradrenergic nature of
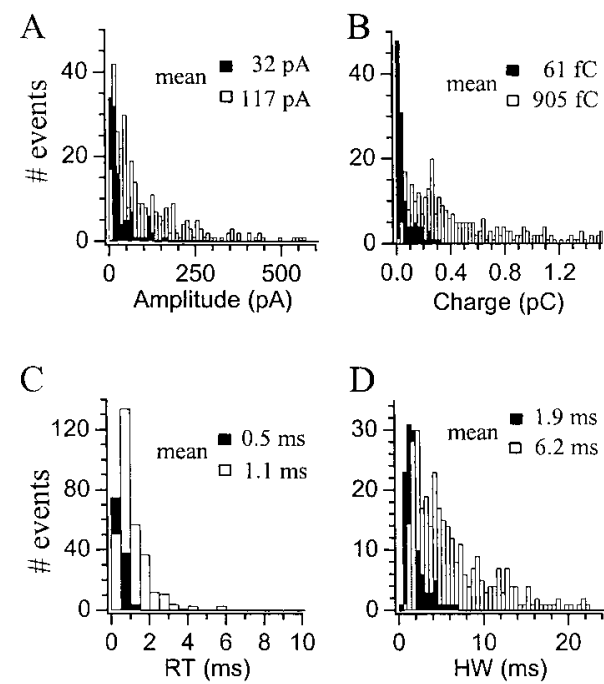

$\mathrm{D}$
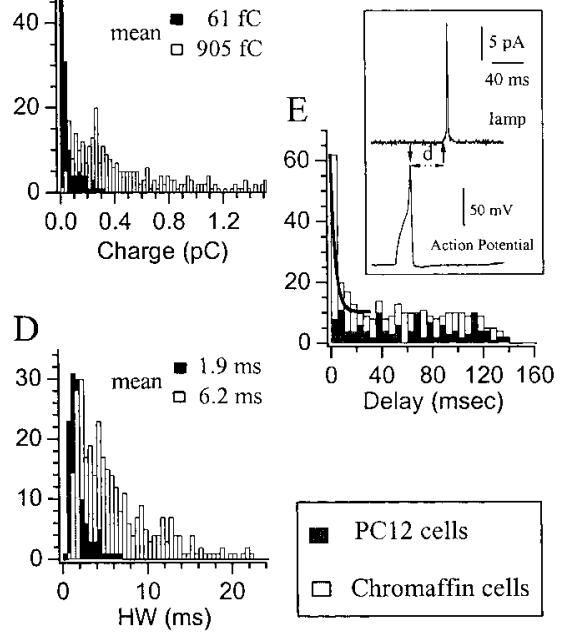
Delay (msec)

Figure 4. Analysis of amperometric spike characteristics in PC12 cells as compared with calf AC cells. Histograms of amplitude $(A)$, total charge $(B)$, rise time $(C)$, and half width $(D)$ distributions in PC12 (shaded bars) and calf AC cells (open bars); mean values are indicated above each panel. $E$, Latency histogram obtained by calculation of the delay between the peak of the action potential and the start of the ensuing amperometric spike (see inset). Note that calf AC cells have a peak of strongly coupled and a plateau of weakly coupled secretion (defined as delays of $<25$ and $>25$ msec, respectively) (Elhamdani et al., 1998), whereas secretion in differentiated PC12 cells is mainly weakly coupled. The line in calf AC cell plot is best fit exponential decay of the strongly coupled phase.

PC12 cells (Greene and Tischler, 1976). The mean number of catecholamine molecules released per quantal event as calculated from the average $Q$ was $2.2 \times 10^{5}$ for PC12 cells as compared with $3.8 \times 10^{6}$ for calf AC cells (cf. Wightman et al., 1995). The quantal content of dexamethasone-treated PC12 cells is about twice that previously reported for untreated cells (Zerby and Ewing, 1996), supporting the idea that catecholamine storage is increased after glucocorticoid treatment (Tischler et al., 1983).

\section{Capacitance measurements of exocytosis and RE}

An alternative method of assessing exocytosis as well as endocytosis is measurement of cell membrane capacitance $\left(C_{\mathrm{m}}\right)$. Previ- 
Table 2. Statistical analysis of individual amperometric spikes in differentiated PC12 cells compared with calf AC cells

\begin{tabular}{|c|c|c|c|c|c|c|c|}
\hline Cell type & RT (msec) & $\mathrm{HW}$ (msec) & Charge (fC) & $\begin{array}{l}\text { Cubic root } \\
\text { charge }(\mathrm{fC})^{1 / 3}\end{array}$ & $\begin{array}{l}\text { Amplitude } \\
(\mathrm{pA})\end{array}$ & $\begin{array}{l}\mathrm{Amp} / \mathrm{Q} \\
(\mathrm{pA} / \mathrm{pC})\end{array}$ & $\begin{array}{l}\text { Number of } \\
\text { events/AP }\end{array}$ \\
\hline $\mathrm{PC} 12(n=14)$ & $0.55 \pm 0.06$ & $2.23 \pm 0.24$ & $72 \pm 12$ & $378 \pm 22$ & $31.4 \pm 5.6$ & $349 \pm 40$ & $0.13 \pm 0.02$ \\
\hline $\mathrm{AC}(n=10)$ & $1.18 \pm 0.08$ & $6.4 \pm 0.3$ & $1210 \pm 170$ & $960 \pm 50$ & $143 \pm 25$ & $96 \pm 6$ & $0.38 \pm 0.02$ \\
\hline
\end{tabular}



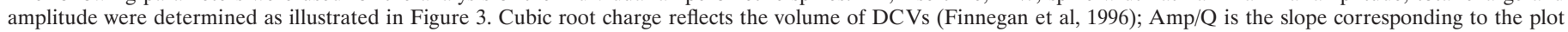
of the amplitude versus charge; Number of events/AP is the average number of amperometric spikes in a 70 sec stimulation at $7 \mathrm{~Hz}$ (490 APs).

A

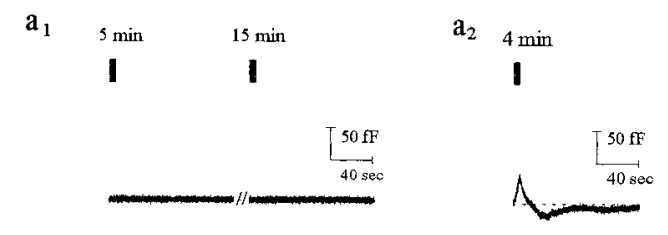

B Differentiated cells

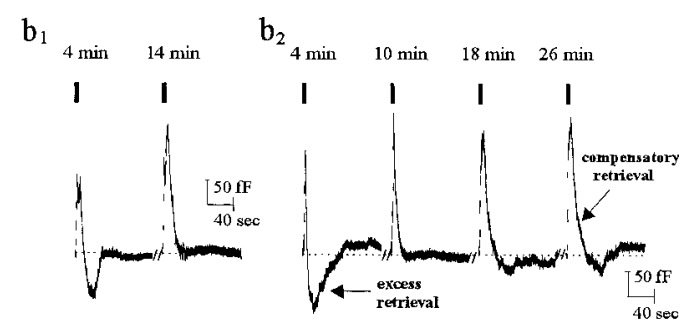

Figure 5. Development of rapid exocytosis and endocytosis in dexamethasone-differentiated $\mathrm{PC} 12$ cells. Continuous $C_{\mathrm{m}}$ records were taken from undifferentiated $(A)$ or differentiated $(B)$ PC12 cells. Cells were stimulated at the times indicated (bars above traces) with $10 \times 50 \mathrm{msec}$ depolarizations to $+10 \mathrm{mV}$. Most naïve PC12 cells exhibited no response (Aa1), but a few cells gave weak responses (Aa2). In all differentiated cells, at least two rounds of $C_{\mathrm{m}}$ increase and decrease (exocytosis and endocytosis) could be evoked (Bb1). Some cells exhibited multiple rounds of exocytosis/endocytosis $(B b 2)$. In these cells $\mathrm{RE}$ was characterized by excess retrieval in the first round and by compensatory retrieval in subsequent rounds to identical stimulations.

ous studies in which naïve PC12 cells were subjected to high intracellular $\mathrm{Ca}$ loads by flash photolysis revealed only slow $C_{\mathrm{m}}$ increases and decreases accompanying catecholamine release (Ninomiya et al., 1997). However, in some systems that secrete via DCVs, rapid exocytotic and endocytotic processes have been described (Heinemann et al., 1994; Thomas et al., 1994; Artalejo et al., 1995, 1996; Eliasson et al., 1996; Kits and Mansvelder, 1998). In the light of the amperometry results presented above, we surmised that exocytotic responses would be sluggish in naïve PC12 cells but swift once the cells were differentiated. This assumption turned out to be correct (Fig. 5). Most untreated PC12 cells showed no capacitance change with depolarizing pulses (Fig. 5Aal), with a minority exhibiting weak responses (Fig. 5Aa2). After dexamethasone treatment, much larger $\mathrm{C}_{\mathrm{m}}$ changes were found (Fig. $5 B$ ) that resembled, in many respects, previous results with calf AC cells (Artalejo et al., 1995). Cells could routinely be stimulated for two successive rounds of $C_{\mathrm{m}}$ increases and decreases (Fig. 5Bb1), and when tested, many cells exhibited several such cycles (Fig. 5Bb2). In these experiments the average rate of exocytosis was $362.4 \pm 17.4(n=30) \mathrm{fF} / \mathrm{sec}$.

After exocytosis, membrane retrieval has been found to occur instantaneously in several secretory systems, including those using
DCVs (for review, see Henkel and Almers, 1996). We have termed this process RE (Artalejo et al., 1995) and hypothesize that it may be the first step in vesicle recycling in neurons and neuroendocrine cells (Palfrey and Artalejo, 1998). RE is measured as an immediate decline in $C_{\mathrm{m}}$ after the increase that occurs when cells are stimulated to secrete (Artalejo et al., 1995). As indicated above, RE was negligible in untreated PC12 cells (Fig. 5A) but occurred reproducibly in differentiated cells (Fig. $5 B$ ). A delay before onset was not observed (cf. Kasai et al., 1996), but like calf AC cells (Artalejo et al., 1995, 1996) and pituitary melanocytes (Thomas et al., 1994), a pronounced overshoot, termed "excess retrieval," was seen in the first round of stimulation but tended to disappear in subsequent rounds (labeled "compensatory retrieval" in Fig. 5Bb2). Although the nature of excess retrieval is unknown [but see Artalejo et al. (1996) for discussion], we did not find that it correlated with the amount of Ca entering the cell (cf. Smith and Neher, 1997), because both excess and compensatory retrieval could be elicited in the same cell with identical depolarizations. These results agree with our original findings in calf AC cells (Artalejo et al., 1995, their Fig. 1). The rates of RE in PC12 cells were also similar to those of calf AC cells: three time constants were observed (ultrafast $\tau=0.3 \pm$ $0.03 \mathrm{sec}$; fast fat $_{1} \tau=2.67 \pm 0.3 \mathrm{sec}$; fast f $_{2} \tau=8.63 \pm 0.54 \mathrm{sec}$; all means \pm SEM; $n=20)$. In contrast to earlier data obtained from growing PC12 cells (Ninomiya et al., 1997), we did not observe distinct types and kinetics of exocytosis-endocytosis in dexamethasone-differentiated PC12 cells. Instead, exocytosis and RE comprised a single cycle, suggesting that a uniform vesicle type (presumably DCVs) is involved. This seems reasonable because it has been shown that smaller (presumptive cholinergic) vesicles disappear in glucocorticoid-treated PC12 cells (Schubert et al., 1980) along with a marked attenuation of acetylcholine synthesis and storage (Berse and Blusztajn, 1997).

\section{RE is dependent on Ca; Ba or Sr does not substitute}

It has been reported in several systems that triggered endocytosis after secretion is a Ca-dependent process [see references in Palfrey and Artalejo (1998)]. Because exocytosis is also Ca driven, and endocytosis in secretory systems is dependent on previous exocytosis, it is frequently difficult to directly determine the divalent cation dependence of the endocytotic arm of the process. One solution to this dilemma is divalent cation substitution experiments. We found previously that although exocytosis could be adequately supported by $\mathrm{Ca}, \mathrm{Ba}$, or $\mathrm{Sr}$, RE was supported only by Ca in calf AC cells (Artalejo et al., 1995, 1996). Hence we performed experiments in dexamethasonedifferentiated PC12 cells to assess whether RE was Ca-specific. As shown in Figure 6, exocytosis was activated when either Ba or $\mathrm{Sr}$ was substituted for $\mathrm{Ca}$ in the bathing solution, but $\mathrm{RE}$ was completely blocked. These results show that RE is relatively specific for $\mathrm{Ca}$ and suggest that the divalent cation receptors for exocytosis and RE are distinct molecular entities in PC12 cells. 




Figure 6. $\mathrm{RE}$ is $\mathrm{Ca}$ dependent in dexamethasone-differentiated $\mathrm{PC} 12$ cells. Continuous $C_{\mathrm{m}}$ records were taken from cells sequentially exposed to $\mathrm{Ca}-, \mathrm{Ba}-$, and $\mathrm{Sr}$-containing solutions. Note that exocytosis $\left(C_{\mathrm{m}}\right.$ rise $)$ occurs with all three divalent cations, but that $\operatorname{RE}\left(C_{\mathrm{m}}\right.$ decline $)$ is abolished in $\mathrm{Ba}$ and $\mathrm{Sr}$. Results from a typical experiment repeated five times are shown.

\section{RE involves dynamin-1}

Dynamin has been shown to play a role in both receptormediated and rapid endocytosis and also in the internalization of caveolae from the plasma membrane (for review, see van der Bliek, 1999). Dynamin isoforms exhibit distinct tissue distributions, and we have suggested that they may be preferentially involved in different types of endocytosis (Artalejo et al., 1997). We confirmed that the PC12 cells used in this study expressed both dynamin-1 and -2 at the mRNA level using both RT-PCR and Northern blotting (data not shown) (cf Sontag et al., 1994) and confirmed that both proteins were expressed using isoformspecific antibodies (Fig. 7A). Introduction of preimmune $\mathrm{IgG}$ (Fig. $7 B$ ) had no effect on RE, but loading of anti-pan-dynamin IgG (Fig. 7C) into PC12 cells blocked RE but had no effect on exocytosis or $\mathrm{Ca}$ currents. Our previous results using the $\mathrm{PH}$ domains of various dynamins together with several mutants showed that dynamin-1 is specifically involved in calf AC cell RE (Artalejo et al., 1997). Consistent with this result, introduction of the recombinant $\mathrm{PH}$ domain of dynamin-1 into PC12 cells via the patch pipette led to an abolition of RE, with no effect on the previous exocytosis (Fig. 7D). These data thus suggest that dynamin-1 is intimately involved in the regulation of RE in differentiated PC12 cells and that this process is similar to that in calf AC cells.

\section{DISCUSSION}

Glucocorticoids are critical inducers of the chromaffin cell phenotype in the differentiating sympathoadrenal lineage (for review, see Anderson, 1993), and their continuous presence may be required to suppress the "default" sympathetic neuronal phenotype (Unsicker et al., 1978; Doupe et al., 1985) [but see also Finotto et al. (1999)]. Growing PC12 cells resemble immature chromaffin cells but express several characteristics of either sympathetic neurons or chromaffin cells on treatment with NGF or glucocorticoids, respectively (Greene and Tischler, 1976; Schubert et al., 1980). NGF decreases the specific activity of all the catecholamine-synthesizing enzymes while simultaneously increasing choline acetyltransferase and vesicular acetylcholine transport and acetylcholine content (Greene and Tischler, 1976). By contrast, glucocorticoids elevate catecholamine biosynthesis and storage (Schubert et al., 1980; Tischler et al., 1983) and
A
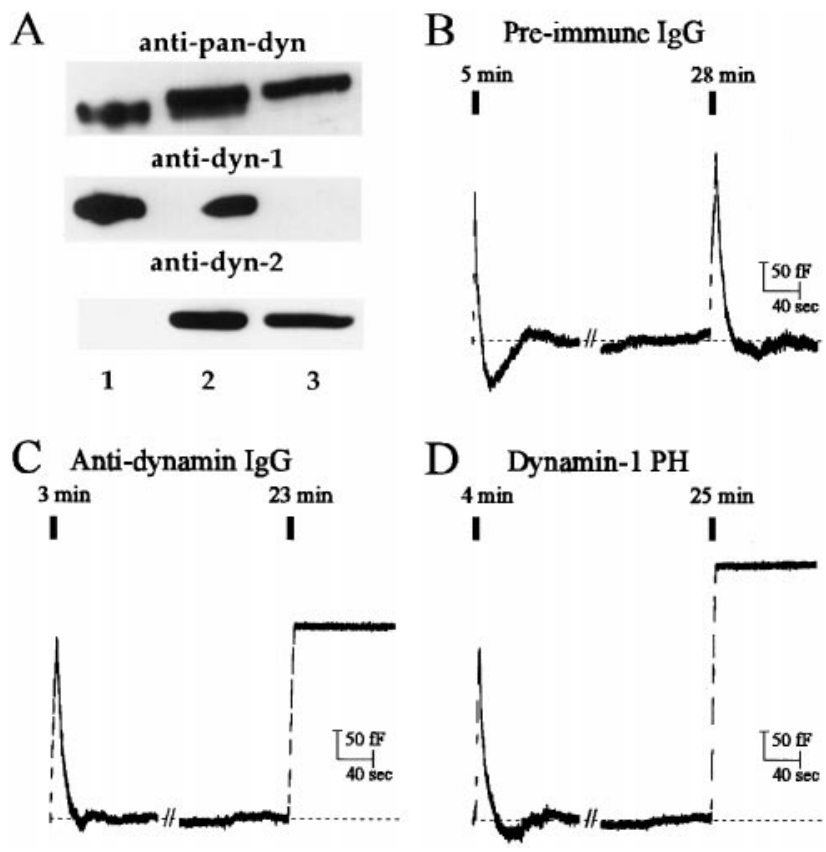

Figure 7. Expression of dynamin isoforms in differentiated PC12 cells and inhibition of RE by anti-dynamin antibodies and dynamin-1 $\mathrm{PH}$ domains. $A$, Immunoblot analysis of dynamin isoform expression. Total extracts of lane 1, rat brain synaptosomes $(10 \mu \mathrm{g})$, lane 2, PC12 cells, and lane 3, 3T3 fibroblasts (75 $\mu \mathrm{g}$ each) were resolved by SDS-7.5\% PAGE, transferred to nitrocellulose, and immunoblotted with either anti-pandynamin or anti-dynamin-1 or -2-specific IgGs. Synaptosomes do not contain dynamin-2, and 3T3 cells do not express dynamin-1, but PC12 cells express both isoforms. $B, C$, Preimmune $\operatorname{IgG}(B)$ or the anti-pandynamin $\operatorname{IgG}(C)$ used in $A$ (top panel) were included in the patch pipette at $1 \mathrm{mg} / \mathrm{ml}$, and cells were tested for exocytosis and RE. Note that RE is intact in the first round before $\mathrm{IgG}$ diffusion from the patch pipette, but that after several minutes, RE is completely inhibited. $D$, Inhibition of $\mathrm{RE}$ by dynamin-1 PH domains. Recombinant dynamin-1 PH domain $(1 \mathrm{mg} / \mathrm{ml})$ was dialyzed into the patch-pipette solution, and cells were tested for exocytosis and RE in a manner similar to $B$.

decrease acetylcholine synthesis by $>80 \%$ over untreated cells (Schubert et al., 1980; Berse and Blusztajn, 1997). We show here that, in addition, induction of the chromaffin cell phenotype upregulates $\mathrm{Ca}$ channel density and enhances coupling between these channels and catecholamine secretion.

In agreement with previous studies, we find that undifferentiated PC12 cells are relatively unexcitable (Dichter et al., 1977) and display very small Ca currents (Streit and Lux, 1987; Garber et al., 1989; Janigro et al., 1989; Usowicz et al., 1990). Over a 7 d period, dexamethasone treatment markedly increases overall $\mathrm{Ca}$ current magnitude and has a particularly striking effect on L-type currents that are virtually undetectable in untreated cells. These results recall those recently obtained in cultured primary rat and porcine chromaffin cells, where the corticosteroid also increased L-type currents (Fuller et al., 1997a,b). On the other hand, NGF treatment of PC12 cells seems to preferentially increase N-type Ca channel density (Plummer et al., 1989; Usowicz et al., 1990; Liu et al., 1996), although dihydropyridine-sensitive channels are still present. Earlier studies using chronic depolarization of undifferentiated PC12 cells showed that dihydropyridines effectively block bulk dopamine secretion (Kongsamut and Miller, 1986), in apparent conflict with our finding of negligible L-type currents in such cells. The resolution of this contradiction may lie in the ability of the few L-type channels present to remain open for long 
periods, with prolonged depolarization allowing a buildup of sufficient $[\mathrm{Ca}]_{i}$ to promote release. We found that acutely stimulated secretion in dexamethasone-differentiated cells showed a slight preference for L-type Ca channels over the N- and P-type channels that are also present. Interestingly, catecholamine secretion is more closely associated with activation of N-type $\mathrm{Ca}$ channels in NGF-differentiated cells, whereas dihydropyridines exhibit minimal effects (Kongsamut and Miller, 1986). It is evident therefore that the coupling between $\mathrm{Ca}$ channel subtypes and secretion is differentially affected when cells mature in either the neuronotopic or adrenotopic direction.

Besides the development of increased catecholamine storage and $\mathrm{Ca}$ current magnitude, glucocorticoid-differentiated PC12 cells exhibit a dramatic enhancement in secretory rate and capacity. The average delay between the peak of the action potential and extracellular amperometric spike was $\sim 50 \mathrm{msec}$, which is comparable to values found previously in adult bovine (Elhamdani et al., 1998) and rat (Zhou and Misler, 1995) chromaffin cells, but much shorter than the values obtained in undifferentiated PC12 cells subjected to either Ca loading ( $\sim 10 \mathrm{sec})$ (Ninomiya et al., 1997) or high $[\mathrm{K}]$ depolarization ( $\sim 6 \mathrm{sec})$ (Zerby and Ewing, 1996). This $\sim 100$-fold difference in secretory rate is unlikely to be caused solely by the increased $\mathrm{Ca}$ current magnitude we found in steroid-treated cells, because the global $\mathrm{Ca}$ increase of $\sim 50 \mu \mathrm{M}$ reportedly achieved in previous flashphotolysis experiments on undifferentiated cells (Kasai et al., 1996) was probably sufficient to saturate the Ca receptors responsible for secretion. Cumulative integral amperometric current was found to be $>10$ times higher in dexamethasone-treated cells than in untreated populations. This is significantly more than the reported increase in catecholamine content after glucocorticoid treatment (Greene and Rein, 1977), so it presumably reflects a difference in the secretory process itself rather than in the amount of catecholamine per DCV. We conclude from these data that the coupling between $\mathrm{Ca}$ channels and the secretory apparatus is markedly enhanced by dexamethasone. This might involve the development of protein assemblies that link $\mathrm{Ca}$ channels with vesicles, as has been found with both $\mathrm{N}$ - and L-type Ca channels (Sheng et al., 1996; Wiser et al., 1999).

Rapid exocytosis is also apparent in capacitance recordings from dexamethasone-differentiated PC12 cells and is reproducibly followed by RE. These results are qualitatively similar to those obtained previously with calf AC cells (Artalejo et al., 1995, 1996) but differ from results obtained previously in untreated PC12 cells. In the latter studies, generation of massive Ca transients by photolysis of loaded $\mathrm{Ca}$ chelators stimulated both fast and slow $C_{\mathrm{m}}$ changes interpreted as arising from different populations of vesicles, possibly secreting acetylcholine and catecholamines, respectively (Kasai et al., 1996; Ninomiya et al., 1997). On the basis of these data, a model proposing that the exocytotic and endocytotic rates of DCVs are much slower than from synaptic-like vesicles was elaborated (Kasai, 1999). By contrast, we show here that exocytosis and endocytosis of DCVs can occur very rapidly, providing that the cells are appropriately differentiated. Our work represents the first description of RE in the PC12 cell line and indicates that membrane retrieval mechanisms coupled to exocytosis are also developmentally regulated. The kinetics of RE in differentiated PC12 cells resemble those previously obtained in calf AC cells (Artalejo et al., 1995, 1996, 1997) and other secretory cells that display an analogous process (for review, see Henkel and Almers, 1996; Palfrey and Artalejo, 1998). We have hypothesized that RE represents an integral step in the vesicle recycling process and may be related to "kiss-andrun" exocytosis (Palfrey and Artalejo, 1998). Although the molecular basis of RE is poorly understood, we have shown that RE does not involve clathrin and is kinetically and mechanistically distinct from the ubiquitous clathrin-coated vesicle mechanism of endocytosis (Artalejo et al., 1995, 1996; Palfrey and Artalejo, 1998). Using a divalent cation substitution approach, we also showed that $\mathrm{RE}$ is $\mathrm{Ca}$-specific in calf $\mathrm{AC}$ cells, and processes similar to RE have been found to be $\mathrm{Ca}$ sensitive in a number of cases (Palfrey and Artalejo, 1998). RE in PC12 cells also appears to be $\mathrm{Ca}$ dependent, as shown by its activation when stimulation is conducted in extracellular $\mathrm{Ca}$ but not in the presence of $\mathrm{Ba}$ or Sr. We showed previously that it is unlikely that the failure of RE with either $\mathrm{Ba}$ or $\mathrm{Sr}$ is caused by inhibition of some component of the endocytotic machinery. Related work shows that Ba does not support an RE-like process in insulinoma cells (Richmond et al., 1996) and reduces stimulus-dependent endocytosis of the dye FM1-43 in nerve terminals [Cousin and Robinson, 1998; for Sr, see Guatimosim et al., (1998)]. Although these results are from disparate systems using different methodologies, they are at least consistent with our hypotheses that $\mathrm{RE}$ is $\mathrm{Ca}$ dependent and that the divalent cation receptors for exocytosis and RE are different (Artalejo et al., 1995, 1996).

Kasai et al. (1996) described a slow $C_{\mathrm{m}}$ decline thought to represent presumptive DCV endocytosis in undifferentiated PC12 cells. In addition to the slower kinetics, distinct lag before onset, and lack of clear $\mathrm{Ca}$ dependence, there are other differences between the endocytotic process described in that and the present work. During membrane retrieval, Kasai et al. (1996) observed irregular $C_{\mathrm{m}}$ jumps, reflective of internalization of membrane regions much larger than individual DCVs. Indeed, these events may reflect the retrieval of non-DCV-related membrane regions. It is known, for example, that photoreleased Ca can induce $C_{\mathrm{m}}$ changes in cells that lack bona fide secretory vesicles (Coorssen et al., 1996), and such "secreted" vesicular membrane might contribute to $C_{\mathrm{m}}$ decline after stimulation. By contrast, in the present study RE is characterized by a smooth profile inconsistent with the recovery of large membrane chunks but compatible with the sequential retrieval of many individual DCVs, as predicted in the kiss-and-run model. The involvement of dynamin-1 in PC12 RE confirms our previous results with calf AC cells. We have suggested that dynamin-1 may be preferentially linked with RE, whereas the ubiquitous dynamin-2 is associated with receptormediated or clathrin-coated vesicle-mediated endocytotic processes (Artalejo et al., 1997).

It is interesting to speculate on the developmental relationship between glucocorticoids and catecholamine release from chromaffin cells as modeled in the PC12 cell system described here. Stressors result in the release of both cortisol and epinephrine from the adrenal gland into the circulation, and both are critical to the full-fledged stress response. It may well be that these two events are linked in that cortisol might maintain a high degree of coupling between $\mathrm{Ca}$ channels and catecholamine release by the adrenal medulla, in addition to its well known induction of catecholamine synthetic enzymes (Wurtman et al., 1972). The continued presence of glucocorticoids appears to be necessary into adulthood to maintain the chromaffin cell phenotype in some animals (Anderson, 1993), and this may extend to the expression of Ca channels (Fuller et al., 1997a,b) and their coupling to secretion. Regulation of $\mathrm{K}$ channels involved in chromaffin cell action potential generation (and consequently secretion) are also affected by steroid levels in the adult rat (Xie and McCobb, 1998). 
From our previous results (Elhamdani et al., 1998) and those presented here, it is apparent that secretion from DCVs may be rapid or slow depending on the coupling between $\mathrm{Ca}$ channels and the secretory apparatus and, contrary to current opinion (Kasai, 1999), need not be an intrinsic property of the DCV exocytotic machinery itself. Developmental events can evidently change the speed of secretion by altering the coupling efficiency. Whether this phenomenon involves the synthesis of new components of the secretory machinery is currently unknown. We speculate that glucocorticoids are necessary for maintenance of strongly coupled secretion in chromaffin cells and could underlie developmental changes in the pattern of catecholamine secretion in maturing organisms (Elhamdani et al., 1998).

\section{REFERENCES}

Anderson DJ (1993) Molecular control of cell fate in the neural crest: the sympathoadrenal lineage. Annu Rev Neurosci 16:129-158.

Artalejo CR, Adams ME, Fox AP (1994) Three types of Ca channel trigger secretion with different efficacies in chromaffin cells. Nature 367:72-76.

Artalejo CR, Henley J, McNiven MA, Palfrey HC (1995) Rapid endocytosis coupled to exocytosis in adrenal chromaffin cells involves $\mathrm{Ca}^{2+}$, GTP and dynamin but not clathrin. Proc Natl Acad Sci USA 92:8328-8332.

Artalejo CR, Elhamdani A, Palfrey HC (1996) Calmodulin is the divalent cation receptor for rapid endocytosis, but not exocytosis, in adrenal chromaffin cells. Neuron 16:195-205.

Artalejo CR, Lemmon MA, Schlessinger J, Palfrey HC (1997) Specific role for the $\mathrm{PH}$ domain of dynamin-1 in the regulation of rapid endocytosis in adrenal chromaffin cells. EMBO J 16:1565-1574.

Berse B, Blusztajn JK (1997) Modulation of cholinergic locus expression by glucocorticoids and retinoic acid is cell-type specific. FEBS Lett 410:175-179.

Brady MJ, Nairn AC, Wagner JA, Palfrey HC (1990) Nerve growth factor-induced down-regulation of calmodulin-dependent protein $\mathrm{ki}$ nase III in PC12 cells involves cyclic AMP-dependent protein kinase. J Neurochem 54:1034-1039.

Chow R, von Ruden L, Neher E (1992) Delay in vesicle fusion revealed by electrochemical monitoring of single secretory events in adrenal chromaffin cells. Nature 356:60-63.

Coorssen JR, Schmitt H, Almers W (1996) $\mathrm{Ca}^{2+}$ triggers massive exocytosis in Chinese hamster ovary cells. EMBO J 15:3787-3791.

Coupland RE (1968) Determining sizes and distribution of sizes of spherical bodies such as chromaffin granules in tissue sections. Nature 217:384-388.

Cousin MA, Robinson PJ (1998) $\mathrm{Ba}^{2+}$ does not support synaptic vesicle retrieval in rat cerebrocortical synaptosomes. Neurosci Lett 253:1-4.

Dichter MA, Tischler AS, Greene LA (1977) Nerve growth factorinduced increase in electrical excitability and acetylcholine sensitivity of a rat pheochromocytoma cell line. Nature 268:501-504.

Doupe AJ, Landis SC, Patterson PH (1985) Environmental influences in the development of neural crest derivatives: glucocorticoids, growth factors, and chromaffin cell plasticity. J Neurosci 5:2119-2142.

Elhamdani A, Zhou Z, Artalejo CR (1998) Timing of dense-core vesicle exocytosis depends on the facilitation L-type $\mathrm{Ca}$ channel in adrenal chromaffin cells. J Neurosci 18:6230-6240.

Elhamdani A, Martin TF, Kowalchyk JA, Artalejo CR (1999) $\mathrm{Ca}^{2+}$. dependent activator protein for secretion is critical for the fusion of dense-core vesicles with the membrane in calf adrenal chromaffin cells. J Neurosci 19:7375-7383.

Eliasson L, Proks P, Ammala C, Ashcroft FM, Bokvist K, Renstrom E, Rorsman P, Smith PA (1996) Endocytosis of secretory granules in mouse pancreatic beta-cells evoked by transient elevation of cytosolic calcium. J Physiol (Lond) 493:755-767.

Finnegan JM, Pihel K, Cahill PS, Huang L, Zerby SE, Ewing AG, Kennedy RT, Wightman RM (1996) Vesicular quantal size measured by amperometry at chromaffin, mast, pheochromocytoma, and pancreatic beta-cells. J Neurochem 66:1914-1923.

Finotto S, Krieglstein K, Schober A, Deimling F, Lindner K, Bruhl B, Beier K, Metz J, Garcia-Arraras JE, Roig-Lopez JL, Monaghan P,
Schmid W, Cole TJ, Kellendonk C, Tronche F, Schutz G, Unsicker K (1999) Analysis of mice carrying targeted mutations of the glucocorticoid receptor gene argues against an essential role of glucocorticoid signalling for generating adrenal chromaffin cells. Development 126:2935-2944

Fuller LZ, Lu C, McMahon DG, Alaudin E, Jorgensen MS, Rau SW, Sisken JE, Jackson BA (1997a) Effect of dexamethasone on voltagegated $\mathrm{Ca}^{2+}$ channels and cytosolic $\mathrm{Ca}^{2+}$ in rat chromaffin cells. NeuroReport 8:1169-1172.

Fuller LZ, Lu C, McMahon DG, Lindemann MD, Jorgensen MS, Rau SW, Sisken JE, Jackson BA (1997b) Stimulus-secretion coupling in porcine adrenal chromaffin cells: effect of dexamethasone. J Neurosci Res 49:416-424.

Garber SS, Hoshi T, Aldrich RW (1989) Regulation of ionic currents in pheochromocytoma cells by nerve growth factor and dexamethasone. J Neurosci 9:3976-3987.

Greene LA, Rein G (1977) Release, storage and uptake of catecholamines by a clonal cell line of nerve growth factor (NGF) responsive pheochromocytoma cells. Brain Res 129:247-263.

Greene LA, Tischler AS (1976) Establishment of a noradrenergic clonal line of rat adrenal pheochromocytoma cells which respond to nerve growth factor. Proc Natl Acad Sci USA 73:2424-2428.

Guatimosim C, Romano-Silva MA, Gomez MV, Prado MA (1998) Recycling of synaptic vesicles at the frog neuromuscular junction in the presence of strontium. J Neurochem 70:2477-2483.

Heinemann C, Chow RH, Neher E, Zucker RS (1994) Kinetics of the secretory response in bovine chromaffin cells following flash photolysis of caged $\mathrm{Ca}^{2+}$. Biophys J 67:2546-2557.

Henkel AW, Almers W (1996) Fast steps in exocytosis and endocytosis studied by capacitance measurements in endocrine cells. Curr Opin Neurobiol 6:350-357.

Janigro D, Maccaferri G, Meldolesi J (1989) Calcium channels in undifferentiated PC12 rat pheochromocytoma cells. FEBS Lett 255:398-400.

Kasai H (1999) Comparative biology of $\mathrm{Ca}^{2+}$-dependent exocytosis: implications of kinetic diversity for secretory function. Trends Neurosci 22:88-93.

Kasai H, Takagi H, Ninomiya Y, Kishimoto T, Ito K, Yoshida A, Yoshioka T, Miyashita Y (1996) Two components of exocytosis and endocytosis in phaeochromocytoma cells studied using caged $\mathrm{Ca}^{2+}$ compounds. J Physiol (Lond) 494:53-65.

Kim KT, Park DH, Joh TH (1993) Parallel up-regulation of catecholamine biosynthetic enzymes by dexamethasone in PC12 cells. J Neurochem 60:946-951.

Klingauf J, Neher E (1997) Modeling buffered Ca2+ diffusion near the membrane: implications for secretion in neuroendocrine cells. Biophys J 72:674-690.

Kongsamut S, Miller RJ (1986) Nerve growth factor modulates the drug sensitivity of neurotransmitter release from PC-12 cells. Proc Natl Acad Sci USA 83:2243-2247.

Liu H, Felix R, Gurnett CA, De Waard M, Witcher DR, Campbell KP (1996) Expression and subunit interaction of voltage-dependent $\mathrm{Ca}^{2+}$ channels in PC12 cells. J Neurosci 16:7557-7565.

Mansvelder HD, Kits KS (1998) The relation of exocytosis and rapid endocytosis to calcium entry evoked by short repetitive depolarizing pulses in rat melanotropic cells. J Neurosci 18:81-92.

Martin TFJ (1997) Stages of regulated exocytosis. Trends Cell Biol 7:271-276.

Ninomiya Y, Kishimoto T, Yamazawa T, Ikeda H, Miyashita Y, Kasai H (1997) Kinetic diversity in the fusion of exocytotic vesicles. EMBO J 16:929-934.

Palfrey HC, Artalejo CR (1998) Vesicle recycling revisited: rapid endocytosis may be the first step. Neuroscience 83:969-989.

Plummer MR, Logothetis DE, Hess P (1989) Elementary properties and pharmacological sensitivities of calcium channels in mammalian peripheral neurons. Neuron 2:1453-1463.

Richmond JE, Codignola A, Cooke IM, Sher E (1996) Calcium- and barium-dependent exocytosis from the rat insulinoma cell line RINm5F assayed using membrane capacitance measurements and serotonin release. Pflügers Arch 432:258-269.

Rozansky DJ, Wu H, Tang K, Parmer RJ, O'Connor DT (1994) Glucocorticoid activation of chromogranin A gene expression. Identification and characterization of a novel glucocorticoid response element. J Clin Invest 94:2357-2368. 
Sabatini BL, Regehr WG (1999) Timing of synaptic transmission. Annu Rev Physiol 61:521-542.

Schubert D, LaCorbiere M, Klier FG, Steinbach JH (1980) The modulation of neurotransmitter synthesis by steroid hormones and insulin. Brain Res 190:67-79.

Sheng Z, Rettig J, Cook T, Catterall WA (1996) Calcium-dependent interaction of $\mathrm{N}$-type calcium channels with the synaptic core complex. Nature 379:451-454.

Smith C, Neher E (1997) Multiple forms of endocytosis in bovine adrenal chromaffin cells. J Cell Biol 139:885-894.

Sontag JM, Fykse EM, Ushkaryov Y, Liu JP, Robinson PJ, Sudhof TC (1994) Differential expression and regulation of multiple dynamins. J Biol Chem 269:4547-4554.

Streit J, Lux HD (1987) Voltage dependent calcium currents in PC12 growth cones and cells during NGF-induced cell growth. Pflügers Arch 408:634-641.

Sudhof TC (1995) The synaptic vesicle cycle: a cascade of proteinprotein interactions. Nature 375:645-653.

Thomas P, Lee AK, Wong JG, Almers W (1994) A triggered mechanism retrieves membrane in seconds after $\mathrm{Ca}$-stimulated exocytosis in single pituitary cells. J Cell Biol 124:667-676.

Tischler AS, Perlman RL, Morse GM, Sheard BE (1983) Glucocorticoids increase catecholamine synthesis and storage in PC12 pheochromocytoma cell cultures. J Neurochem 40:364-370.

Tomlinson A, Durbin J, Coupland RE (1987) A quantitative analysis of rat adrenal chromaffin tissue: morphometric analysis at tissue and cellular level correlated with catecholamine content. Neuroscience 20:895-904.

Travis ER, Wightman RM (1998) Spatio-temporal resolution of exocytosis from individual cells. Annu Rev Biophys Biomol Struct 27:77-103.
Unsicker K, Krisch B, Otten U, Thoenen H (1978) Nerve growth factor-induced fiber outgrowth from isolated rat adrenal chromaffin cells: impairment by glucocorticoids. Proc Natl Acad Sci USA 75:3498-3502.

Usowicz MM, Porzig H, Becker C, Reuter H (1990) Differential expression by nerve growth factor of two types of $\mathrm{Ca}^{2+}$ channels in rat phaeochromocytoma cell lines. J Physiol (Lond) 426:95-116.

van der Bliek AM (1999) Functional diversity in the dynamin family. Trends Cell Biol. 9:96-102.

Wightman RM, Shroeder TJ, Finnegan JM, Ciolkowski EL, Pihel K (1995) Time course of release of catecholamines from individual vesicles during exocytosis at adrenal medullary cells. Biophys $\mathbf{J}$ 68:383-390.

Wiser O, Trus M, Hernandez A, Renstrom E, Barg S, Rorsman P, Atlas D (1999) The voltage sensitive Lc-type $\mathrm{Ca}^{2+}$ channel is functionally coupled to the exocytotic machinery. Proc Natl Acad Sci USA 96:248-253.

Wurtman RJ, Pohorecky LA, Baliga BS (1972) Adrenocortical control of the biosynthesis of epinephrine and proteins in the adrenal medulla. Pharmacol Rev 24:411-426.

Xie J, McCobb DP (1998) Control of alternative splicing of potassium channels by stress hormones. Science 280:443-446.

Zerby SE, Ewing AG (1996) The latency of exocytosis varies with the mechanism of stimulated release in PC12 cells. J Neurochem 66:651-657.

Zhou Z, Misler S (1995) Action potential-induced quantal secretion of catecholamines from rat adrenal chromaffin cells. J Biol Chem 270: 3498-3505. 